\title{
Chapter 4 \\ Divorce Trends in Seven Countries Over the Long Transition from State Socialism: 1981-2004
}

\author{
Juho Härkönen, Sunnee Billingsley, and Maria Hornung
}

\begin{abstract}
The collapse of communism was a defining geopolitical event of latetwentieth century Europe, with well-documented economic, social, and political implications. Yet there is a striking absence of research on how it influenced divorce. The objective of this study is to provide an exploratory analysis of trends in divorce over the long transition from communism-starting from the decline of the communist economy in the 1980 s and ending with economic revival-in seven countries: Bulgaria, Estonia, Hungary, Lithuania, Poland, Romania, and Russia. We discuss how the transition could be expected to either increase or decrease divorce risks. We analyze retrospective micro-level data on first marriages from the Changing Life Course Regimes in Eastern Europe (CLiCR) dataset. Based on our event-history analyses, we find that divorce rates increased in each country at some stage during the long transition and these increases cannot be explained by compositional change of the marriages. However, no uniform pattern emerged in the timing and duration of the increase in divorce risk. This striking variation leads us to conclude that even the effect of major societal ruptures is contextually contingent.
\end{abstract}

Keywords Divorce $\cdot$ Central and Eastern Europe $\cdot$ Social change $\cdot$ Transition from communism $\cdot$ Event history analysis

\footnotetext{
J. Härkönen $(\triangle)$

European University Institute, Florence, Italy

e-mail: juho.harkonen@eui.eu

S. Billingsley $\cdot$ M. Hornung

Stockholm University, Stockholm, Sweden

e-mail: sunnee.billingsley@ sociology.su.se; maria.hornung@ @ociology.su.se 


\subsection{Introduction}

The fall of communism was one of the defining geopolitical events of late-twentieth century Europe. Besides re-drawing Europe's geopolitical map, the transition from communism to a market economy had a profound impact on the daily lives and living conditions of the populations experiencing it, and previous research has shown how it shaped, among other outcomes, social inequality and social mobility (Gerber and Hout 2004), population health (Billingsley 2011; Brainerd 1998), and marriage and fertility (Billingsley 2010; Billingsley and Duntava 2017; Gerber and Berman 2010; Nedoluzhko and Agadjanian 2015).

Did the transition also affect divorce? The transition from communism meant radical social, political and economic transformations from previous social and economic structures and relations, institutional support systems, and norms. Such societal unravelling and the corresponding instabilities for everyday life likely spill over into marital instability. Yet, as will be discussed in more detail below, many of the repercussions may have had the opposite effect and reduced divorce, for example by increasing economic dependence on the family or by heightening the barriers to divorce. Given the potential impacts of the transition on the family domain, and its documented effects on family formation, there is a striking absence of research on divorce trends in these societies.

The objective of our study is to provide an exploratory analysis of divorce risks between 1981 and 2004 in seven post-communist societies: Bulgaria, Estonia, Hungary, Lithuania, Poland, Romania, and Russia. Our study provides the first cross-nationally comparative analyses of micro-level data on divorce trends over the transition from communism to market-based economies. Previous research on divorce during this period have best documented divorce trends in Russia (Avdeev and Monnier 2000; Solodnikov 2016) and Hungary (Bukodi and Róbert 2003; Spéder 2005; Spéder and Kamarás 2008), and other studies include single-country analyses of divorce trends in Bulgaria (Philipov and Jasilioniene 2008), and Romania (Mureşan et al. 2008), as well as socio-economic determinants of divorce risks in Estonia (Rootalu 2010) and Lithuania (Maslauskaite et al. 2015). To date, the only comparative study on divorce was based on aggregated data (Philipov and Dorbritz 2003).

We asked three questions. First, how did divorce rates develop in the seven countries over the years of transition from state socialism to market-based economies, from 1981 to 2004 ? These years cover the gradual unraveling of the communist system and the perestroika years, the years of institutional and political change, as well as the immediate aftermath, and stabilization of new political and economic systems. In other words, we treat the "long" transition as a gradual process rather than just a discrete event. Second, given the well-documented changes in family formation behavior especially, can any period differences in divorce rates be linked to demographic or compositional features of marriages? Trends based on aggregated data, such as those reported by Philipov and Dorbritz (2003), are suspect to changes in the compositional features of marriages. Our event history analyses on 
harmonized retrospective marital history data from the Changing Life Course Regimes in Eastern Europe (CLiCR) dataset allow us to compare estimated trends net of compositional change. Third, we asked whether any trends detected were similar across the seven countries. As will be discussed in more detail below, some features of the transition were shared by all countries, whereas others-such as value and gender norm changes (Sobotka 2011) and the success of market reforms (Bohle and Greskovits 2007) showed more variation, leading to potentially idiosyncratic responses in divorce rates.

\subsection{Background}

We focus on seven former communist countries that all experienced a transition from a state socialist regime to a market-based economy and democratic political system: Bulgaria, Estonia, Hungary, Lithuania, Poland, Romania and Russia. The transition began with the revolutions of 1989, beginning first in Poland in the summer and spreading to Hungary, Bulgaria and Romania. Estonia and Lithuania established independence from the Soviet Union in September 1991 and the Soviet Union ceased to exist in December 1991, resulting in the establishment of the Russian Federation. This quick pace of events in the 1989-1991 time period was preceded by the birth of the Solidary labor party in 1980 in Poland (which was stifled before independence) and a period of policy reform and openness, perestroika and glasnost, in the Soviet Union that began in 1985. A major impulse for change in the political systems was economic difficulty beginning in the late 1970s.

The transition from communism to a market economy led to major change in politics, society and economic conditions in post-socialist countries (Blanchard 1997; Gerber and Hout 2009). While the socialist system provided job and housing security, a basic income, and financial support to families as well as high availability of childcare, the transition disrupted many of those systems (Barr 2001; Fajth 1999; Frejka 2008; Stankuniene and Jasilioniene 2008). The post-socialist era brought along a decrease in state support and an increased liberalization of the market, which caused an economic crisis in many countries and worsened economic and housing security (Gimpelson 2001) as well as the compatibility of paid and unpaid work for women (Pascall and Manning 2000; Szelewa and Polakowski 2008).

Up until the 1990s, the economies of the Eastern Bloc were interdependent through membership to the Council for Mutual Economic Assistance (COMECON), which was led by the Soviet Union. The collapse of communism and COMECON led to economic decline in every associated country. Figure 4.1 shows that economic difficulties varied, however, in terms of depth and length. The Central and Eastern European (CEE) countries we study all saw a relatively small decline in GDP per capita by 1991. Poland experienced the quickest rebound and steepest economic growth after 1991. Hungary stabilized and saw economic growth steadily after 1991, outperforming all others by 1992. Bulgaria's initial economic decline in 


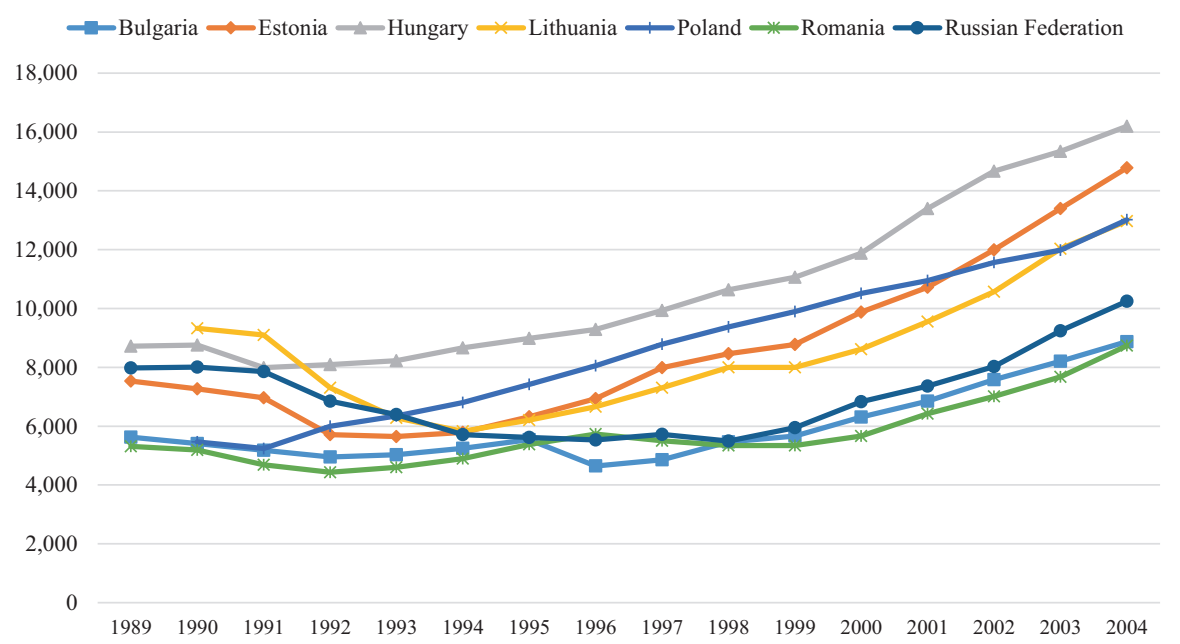

Fig. 4.1 GDP per capita in purchasing power parity (2012 international \$). (TransMonEE 2012)

the early 1990s was minimal, but it experienced a greater recession in 1996 and 1997. Romania's economic recovery mirrored Bulgaria's, except that the economic slowdown occurred from 1997 to 1999 . The countries belonging to the former Soviet Union (FSU) saw much deeper recessions in the early 1990s. Both Baltic countries experienced a fast decline and recovery was clearly evident by 1995 and mostly steady thereafter. Russia, on the other hand, did not show signs of real recovery until 1999.

In Russia, the liberalization of the market led to inflation, recession, unpaid wages, and downward mobility and unemployment (Blanchard 1997; Gerber and Hout 2009). Economic recessions and high inflation also characterized stages of the transition in Bulgaria, Estonia, Lithuania, and Romania, but to a somewhat lesser extent in Hungary and Poland (Bohle and Greskovits 2007; Koytcheva and Philipov 2008; Maslauskaite et al. 2015; Mureşan et al. 2008; Robila 2004; Spéder and Kamarás 2008). Similarly, compared to Russia, where the economic transformation worsened the employment situation for women and increased the gender pay gap, women in other Eastern European countries (Bulgaria, Estonia, Poland, Hungary) gained substantially relative to men (Spéder and Kamarás 2008; Brainerd 2000).

\subsection{Divorce Legislation and Trends}

Divorce rates fluctuated across the communist countries already before the transition. The liberalization of divorce laws in the Soviet Union in the mid-1960s in particular was followed by a general increase in divorce rates (Solodnikov 2016). Whereas most of the communist countries maintained liberal divorce laws from this time onwards and divorce rates continued to increase, divorce in Romania was 
almost inaccessible from 1967 to 1974 (Mureşan 2007). In the late 80s, some divorce laws were made more restrictive, such as in the case of Hungary-which temporarily halted the previous increase in divorce rates (Bukodi and Róbert 2003; Spéder and Kamarás 2008) - and Bulgaria, where fault-based divorce was introduced again (Todorova 2000). The transition from communism was accompanied by another wave of changes in divorce laws. In Romania, liberalized legislation had little observable effect, as the housing crisis, poverty and more negative attitudes towards divorce compared to other European countries kept divorce rates low (Mureşan et al. 2008; Pantea 2013). The Baltic States tried to abandon Soviet family laws in the 1990s by reverting to pre-Soviet legislation. As many former Eastern European countries strove for inclusion into the EU, legislation was aligned with liberal European law concepts that prevented the change of laws from becoming very restrictive (Khazova 2012).

Overall, divorce rates varied between the seven countries both before and during the transition (Fig. 4.2; Philipov and Dorbritz 2003). They were the highest in the Baltic states and Russia—generally on par with Northern Europe — and the lowest in Bulgaria, Romania and Poland. Figure 4.2 shows trends in the total divorce rate (that is, divorces per 100 marriages) in six of our countries (Russia is excluded). For the most part, total divorce rates remained stable throughout the 1980s, but began to increase in many countries after around the collapse of communism. This is most obvious in the Baltic States, but also in Hungary, which were the countries with high divorce rates to begin with. One can detect signs of upward slopes in divorce also in Bulgaria and Romania, and somewhat less clearly in Poland.

Despite these overlaps between divorce trends and the transition from communism, Philipov and Dorbritz (2003) argued that the transition from communism did not lead to any apparent effects on aggregate divorce rates. Rather, they remained low in countries where they were low to begin with, and any increases were mainly

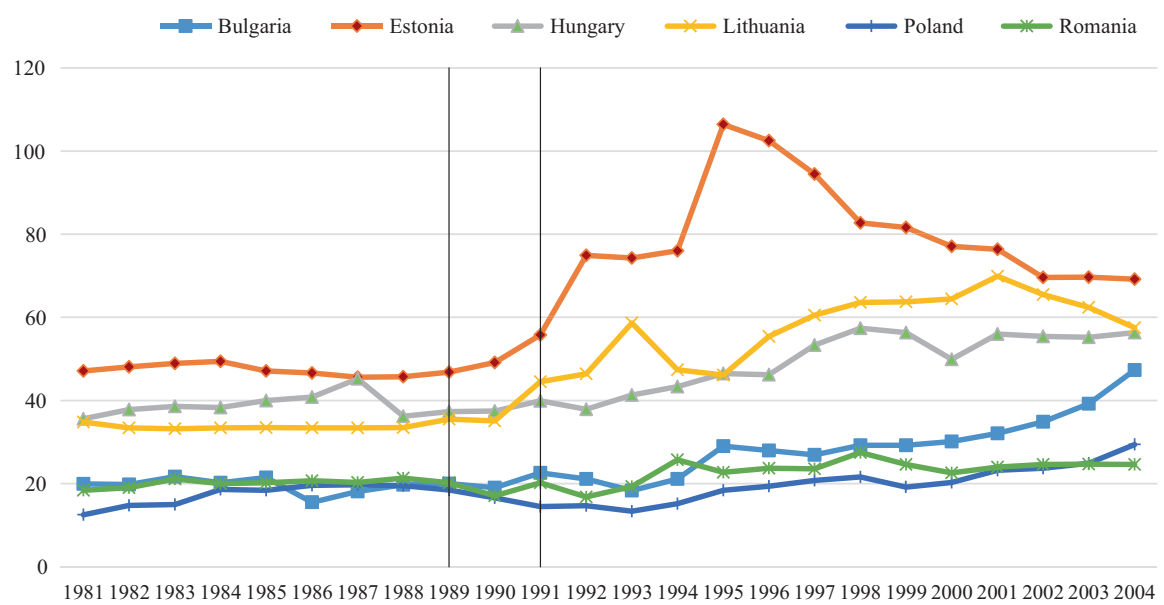

Fig. 4.2 Total divorce rates in six post-communist countries. (Eurostat 2018) 
due to timing effects-assessed through the duration of divorced marriages. Neither was there any evidence of a decrease in divorce during the transition. These conclusions are, however, based primarily on aggregated data. They may therefore be sensitive to any confounding effects due to compositional changes, as well as imperfect measurement of timing effects.

\subsection{Theoretical Links Between the Transition Context and Divorce}

Theoretically, the transition from communism to market-based economies could either increase or decrease divorce risk. Building on sociological and economic theories of divorce (e.g., Becker 1981; Levinger 1976), major social and economic upheavals can increase divorce risk by increasing marital stress or through a shakeup of norms regulating family life, or alternatively decrease divorce risk by exacerbating the costs of divorce and the reliance on family bonds.

The economic crisis followed by gradual demise and subsequent fall of the communist system was the most obvious mechanism to affect divorce. Economic recessions can have either a positive or a negative effect on divorce (Cohen 2014; Philipov and Dorbritz 2003; Sobotka et al. 2011). According to family stress theory (Conger et al. 1990) unemployment and the fall in living standards increase economic stress and negative spousal interactions, thus heightening the risk of divorce during recessions (cf. Fischer and Liefbroer 2006; Sobotka et al. 2011; South 1985). Related to this argument, a decrease in consumer confidence for instance has been shown to increase union dissolution rates in the Netherlands for women from all educational levels (Fischer and Liefbroer 2006). This argument would lead us to expect that due to the economic turmoil surrounding the transition from communism, divorce rates increased during the transition and particularly so in countries in which the economic declines were more pronounced.

Economic crises can also decrease divorce risks by increasing the costs of separation. Recessions reduce the opportunities for independent economic provision and increase economic reliance on the family. The reduction in incomes can also boost the costs of any legal divorce proceedings. Much research from Western countries has found that divorce rates are pro-cyclical (Amato and Beattie 2011; Cohen 2014; Hellerstein and Morrill 2009; Schaller 2013; South 1985), suggesting that recession effects that operate through the costs of divorce trump effects operating through stress mechanisms as couples forego or at least delay divorce during economic downturns. A study by González-Val and Marcén (2017) confirmed a pro-cyclical response of divorce rates for European countries (1991-2012). However, studies with individual data lead to opposing conclusions: unemployment (Kraft 2001) and unexpected earnings decreases (Böheim and Ermisch 2001; Weiss and Willis 1997) have been shown to raise divorce risks (Böheim and Ermisch 2001; Kraft 2001; Weiss and Willis 1997). Nevertheless, there is a gender divide. While unexpected 
increases in earnings decrease divorce risks for men, they increase divorce risks for women (Böheim and Ermisch 2001; Weiss and Willis 1997).

The evidence for effects of economic crises on divorce comes mainly from Western countries. Although the general mechanisms linking economic turmoil to divorce were likely to be similar in the countries experiencing the transition from communism to market economy, the sheer depth of the crisis in the latter suggests that generalizations should be made with caution. In addition to spikes in unemployment and collapses in wage levels, inflation skyrocketed in many countries to four figures. Due to these specificities, predictions of the effects of the economic turmoil on divorce that are based on the Western experience are uncertain.

In addition to its economic effects, the transition from communism to marketbased economies had profound social consequences that may have shaped divorce rates. Despite the important role of social housing in communist ideology aiming at providing housing for everyone, communist countries suffered from a severe shortage of housing. Married couples and families were favored in the socialist housing system, which incentivized early union formation and childbearing (Deacon 1987; Frejka 2008; Hussar 2017; Morton 1979; Turnock 1990). The removal of this system can have removed some of the barriers to divorce as the supply of housing increased after the marketization of the housing sector. Nevertheless, these privatization processes, which in some countries started before the 90 s, simultaneously increased prices in both the private and public housing sector (Hegedüs and Tosics 1992; Tsenkova et al. 1996). Even though all post-communist countries started to privatize their housing market, there was much variation in the extent and the effectiveness of these steps (Clapham and Kintrea 1996). In Russia, for instance, many characteristics from the Soviet housing system such as the underdeveloped quality of housing or the waiting lists remained (Lux and Sunega 2014). In Romania, housing scarcity also remained a problem after the collapse of communism (Robila 2004). In Hungary, the housing system had been privatized early on (Bodnar and Böröcz 1998), but rather than improving the situation for a wide range of people, the privatization introduced new forms of segregation by favoring wealthy households and trapping low-income households in the social renting sector (Hegedüs 2013).

A second factor concerns the gendered effects of the transition. Socialist economies promoted gender equality in the public sphere through centralized wage setting, universal employment and accessible and affordable childcare; one of the consequences of the transition was an increase in the share of women unemployed, the gender wage gap, difficulties managing work and care, and in gender discrimination in many countries (Degtiar 2000; Khotkina 2001; LaFont 2001; Spéder and Kamarás 2008). Although male non-employment has a generally positive effect on divorce rates, female non-employment can stabilize marriages particularly in more traditional countries and where women are more economically dependent on their husbands (Cooke et al. 2013; Härkönen 2014; Lyngstad and Jalovaara 2010), which may have shaped the consequences of the transition from communism on divorce. In Lithuania, female unemployment stabilized marriage only in urban areas, (Maslauskaite et al. 2015) whereas in rural areas, dropping out of the labor market increased the risk of divorce for women (Maslauskaite et al. 2015). For men, 
unemployment in Lithuania is associated with a higher divorce risk. No difference in divorce rates was found in Russia between women who worked and women who did not work in periods during socialism and after the transition (Muszyńska 2008). Vignoli et al. (2018) found no effect of women's employment on divorce in Hungary, but employed women have higher risks of divorce than unemployed women in Poland. An earlier study of the 1940-1992 marriage cohorts in Hungary showed an increased risk of divorce for employed women (Bukodi and Róbert 2003).

The transition also influenced values and attitudes. Historically, the countries differed in their religious affiliation. Russia, Bulgaria, Romania were Orthodox (Fitzpatrick and Kostina-Ritchey 2013; Kte'pi 2013; Pantea 2013), whereas Lithuania, Poland, Hungary were Catholic (Dvorak 2013; Lobodzinska 1983; Palmer and Molenda-Kostanski 2013) and Estonia was predominantly Protestant. The collapse of communist regimes increased insecurity as former guarantees such as employment or free education were not assured, which may have led to a more open embrace of - often previously latent or hidden-Catholic or Orthodox Christianity (Müller 2009; Robila 2004; Spéder and Kamarás 2008). Only in Hungary and Poland is a religious revival not clear and this is the case in Poland primarily because of such high Catholicism already at the dawn of transition from communism. Increased or activated religiosity may also have fueled the retraditionalization or re-familization that occurred in gender roles (Teplova 2007), which may have increased women's perceived and actual dependency on male partners.

At the same time, the waning of socialist values entailed greater personal freedom of thought, expression and lifestyles in most contexts. The changes that occurred in fertility and family behavior around the time of the transition from communism have been recognized as being related to the Second Demographic Transition (Lesthaeghe and Surkyn 2002). This transition is identified through a set of demographic patterns such as increased non-marital cohabitation and postponement of parenthood and presumably is caused by a shift toward post-materialist and individualist values. The opening of borders entailed an influx of ideas and information related to contraception and sexuality, which altered norms related to extramarital sex and pornography (Sobotka 2011). Although the direct link between these changing norms and family behavior has not been explicitly studied, it is plausible that the timing of marriage and potentially selection into marriage changed when non-marital sexual activity and contraception became more accessible. Fewer or later marital unions may in turn lower divorce rates. Stigma associated with divorce also diminished over time in some countries (Karabchuk 2017; PerelliHarris et al. 2017).

The transition also amplified pre-existing social problems, the best documented of which is high alcohol consumption in Russia (Mckee et al. 2001). Evidence shows that a high frequency of drinking is associated with an increased risk of divorce in Russia (Keenan et al. 2013). It is not clear, however, whether alcohol consumption increased detrimentally in other post-communist countries.

Finally, the transition may have contributed to divorce rates indirectly by altering the socio-demographic composition of married couples. The transition was 
accompanied by an increase in the age at marriage (Frejka 2008), which is consistently shown to lower divorce risks (Lyngstad and Jalovaara 2010). On the other hand, non-marital cohabitation became much more common (Gerber and Berman 2010; Hoem et al. 2009; Katus et al. 2007; Philipov and Jasilioniene 2008; Spéder and Kamarás 2008), including both before marriage and re-partnering after divorce. The increase in cohabitation reflects a weakening importance of the institution of marriage, and marriages preceded by cohabitation-either with the same or different partner-are less stable than "direct" marriages. The transition was also accompanied by a clear reduction in fertility (Billingsley 2010; Billingsley and Duntava 2017; Frejka 2008). In Central and Eastern Europe, this was due to a postponement of parenthood primarily, whereas the decline in fertility was more related to fewer second and third births in Estonia, Lithuania and Russia (Billingsley and Duntava 2017). Children, and young children in particular, generally lower divorce risk (Lyngstad and Jalovaara 2010). This would imply that couples postponing parenthood and couples having fewer children overall, would have indirectly increased divorce risks.

Summing up, even though all of the seven countries studied here went through the transition from communism to market-based and democratic societies, the specific features of this transition showed cross-national variation. Theoretically, it is unclear whether the transition should have increased or decreased divorce, and given the national idiosyncracies both in the conditions before the transition and the adaptation to it, it is also unclear whether any trends in divorce can be expected to follow a uniform pattern applying to all seven countries.

\subsection{Analysis}

We use harmonized retrospective life course data from the Changing Life Course Regimes in Eastern Europe (CLiCR) dataset. This is a resource developed by the Stockholm Centre on Health of Societies in Transition at Södertörn University and Stockholm University's Demography Unit. CLiCR combines retrospective data from different sources and the country data sets used in this study come from the Generations and Gender Surveys (GGS) and Fertility and Families Surveys (FFS).

Our sample includes the first marriages of men and women who married between 1966 and 2004, and includes 51,568 individuals, with sample sizes ranging from 3745 in Estonia to 16,268 in Poland. Our dependent variable is divorce, which was defined at the month in which the couple either separated or legally divorced, whichever came first. The marriages were right-censored at death of the partner, at interview, or 15 years (180 months) since the wedding. The sample also included left-truncated cases - that is, marriages that were contracted before we first started observing them in 1981 - for which we set the duration of the marriage to start from the marriage and not the first time they were observed (Guo 1993).

Our primary independent variable is historical period, which was divided into the following years: 1981-1984 (reference), 1985-1988, 1989-1991, 1992-1995, 
1996-2000, and 2001-2004. The reference category reflects the years prior to the perestroika period (1985-1988). These periods reflect a similar starting point for all countries, but they are characterized somewhat differently in later years according to whether a country was part of CEE (Bulgaria, Hungary, Poland and Romania), or part of the FSU (Estonia, Lithuania and Russia). The years 1989-1991 cover the collapse of communism for all countries as well as the recession that immediately followed in the CEE countries. The immediate aftermath for FSU, which included a much deeper economic crisis, is instead reflected in the 1992-1995 period, which is a period of economic and institutional stabilization in CEE (except perhaps for Bulgaria). The subsequent years of the transition (1996-2000) included years of economic recovery for most of CEE but continued economic crisis in Russia. The final period we include in our analysis (2001-2004) are years during which economic recovery occurred for all as well as the period when Estonia, Hungary, Lithuania and Poland joined the European Union. Although the measure does not take into account more specific national variation, it characterizes the main stages that led to the collapse of communism and the transition to the market economy.

In the first stage of the analysis, we estimated Kaplan-Meier hazard curves to describe the development of divorce risks in each of the seven countries. In this descriptive stage, we estimate divorce risks using a period approach, which relies on synthetic cohorts. Respondents contribute to each time periods' hazard estimation as she/he progressed through the periods. This means that individuals can contribute to many different time periods, but their contribution will be specific to the number of months since marriage. The synthetic cohort approach is useful when aiming to show a trend over time periods and avoids introducing selectivity based on postponement of marriage. These hazard curves describe change over time, but because this may be due to compositional change we follow up these analyses with multivariate analysis.

In the second stage of the analysis, we estimated piecewise constant exponential event history models for each country (Blossfeld et al. 2007). Our first model compares divorce risks by historical period, only controlling for marital duration and sex of the respondent. Period effects on divorce risk can be confounded by the effects of marital duration. The divorce risk generally increases during the (approximately 4-7) first years of marriage, and decreases thereafter. We split the data into 2-year (24 months) intervals by marital duration, and control for marital duration by including dummy variables of the split duration episodes, using the first 2 years as the reference category. The duration of marriage is calculated from the start of the marriage also for those left-truncated cases who had already married before 1981, that is, before the first observation period of 1981-1984. Sex of the respondent was controlled for to adjust for any possible sex differences in reports of marital histories.

Our second event history model controlled for additional covariates known to predict divorce. These models were estimated in order to assess whether compositional change of the marriages could drive any of the differences in divorce risks by historical period. As discussed above, the transition from communism to marketbased economies had a range of societal consequences, which in addition to any 
secular trends may have influenced the divorce rates of couples marrying in different stages during the communist era or thereafter.

First, we control for educational attainment, which due to educational expansion increased in many countries, and is a known predictor of divorce in post-communist societies and beyond (Becker and Hemley 1998; Bukodi and Róbert 2003; Härkönen and Dronkers 2006; Karabchuk 2017; Rootalu 2010). This information was based on the highest level of education completed as well as the time of its completion, and is coded into a time-varying measure of educational attainment with three categories: Low, middle and high. Low educational attainment includes less than or completed secondary school, middle includes attending a higher educational institution for less than 3 years (including post-secondary or technical training), and high educational attainment includes at least 3 years of post-secondary education (i.e., university). Because we know the completion date of the highest attained education only, we cannot reconstruct full educational histories of attainment dates of earlier degrees. This would be a problem for those marrying before completing secondary education but who continue to tertiary education. Given that most people marry after completing their education - and secondary education (at age 18-19) in particular - this will not lead to any major bias due to time-ordering of the variables (cf. Hoem 1996; also Härkönen and Dronkers 2006). Our data include information of the educational attainment of the (male or female) respondent only. Because men's and women's education can shape divorce risks differently, we also interact educational attainment with sex.

We also control for age at marriage (of the respondent), whether the respondent cohabited before the marriage and whether the respondent or the partner had any children before the start of their union. In addition, we added time-varying variables for the number of children of the respondent $(0,1,2$, or 3 or more), as well as the presence of a small child ( $<3$ years old). Controlling for these takes into account any changes in divorce rates that may have occurred because of changing patterns of family formation. Marrying at a young age as well as cohabiting before marriage are associated with higher divorce risk (Härkönen and Dronkers 2006; Muszyńska 2008; Muszyńska and Kulu 2007). Having a small child, on the other hand, predicts lower divorce risks (Jasilioniene 2007; Karabchuk 2017; Muszyńska and Kulu 2007). During the communist era, some divorce procedures were more difficult when underage children were present in the family, another reason to control for the age of a child (Moskoff 1983; Goode 1993; Fitzpatrick and Kostina-Ritchey 2013).

Descriptive statistics of these variables in each country sample are displayed in Table 4.1. A few general patterns are noteworthy. First, 55-69\% of all individuals in all samples have medium educational level, whereas the remaining balance falls either on the low or high side; the countries that were previously part of the Soviet Union (Estonia, Lithuania and Russia) had a low share of individuals with only secondary or lower education (between 7-11\% compared to 20-29\% in non-Soviet countries) and tended to have higher shares of university educated individuals. No large differences appeared across these countries in terms of the low average age at first marriage (22-23 years old), number of children (1.3-1.5), whether a child under the age of three was in the household (35-37\%), or whether a partner had a 


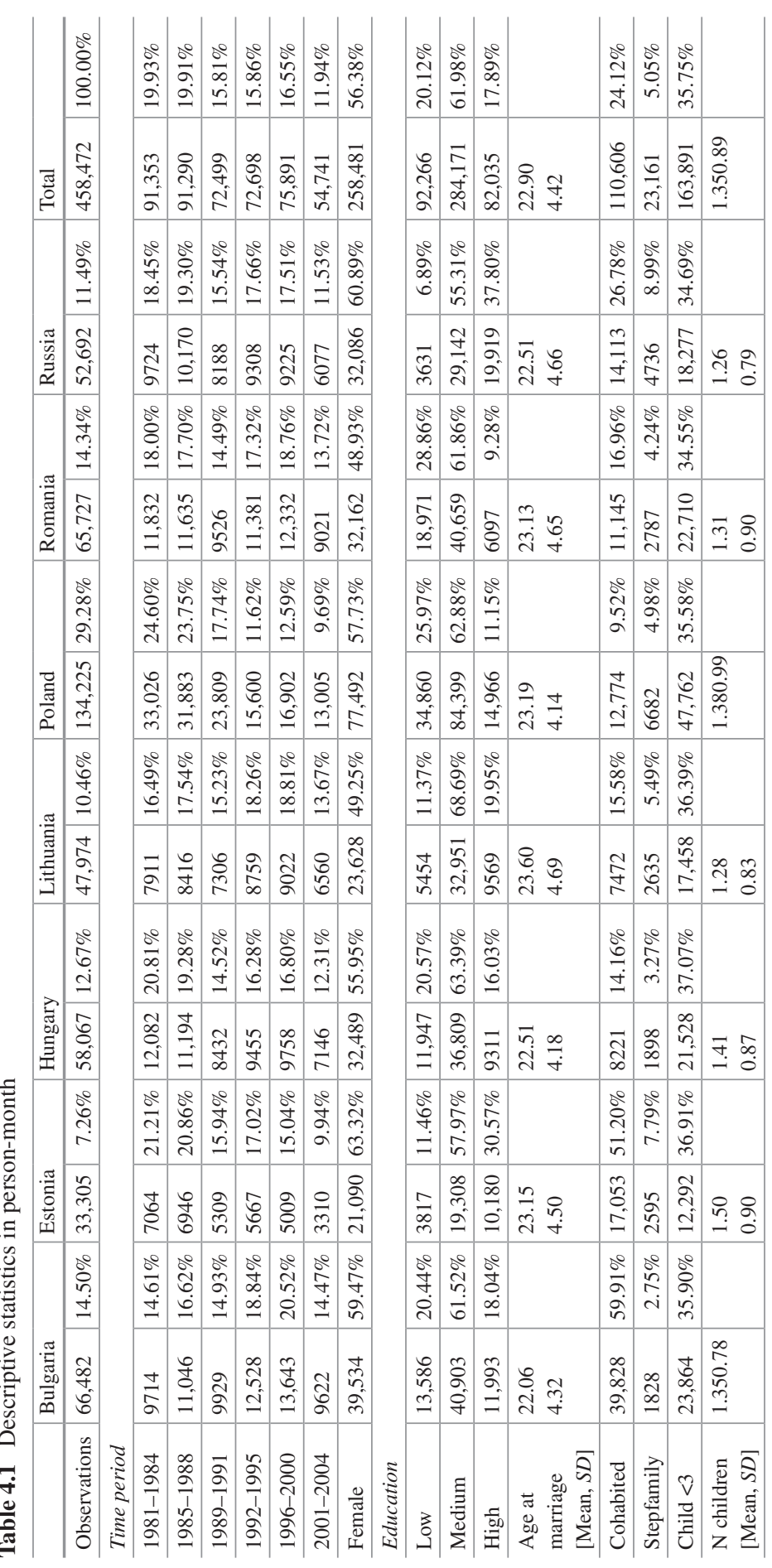


child from a previous partnership (3-9\%). Cohabitation before marriage did vary widely, however, with this being much more common in Bulgaria and Estonia. The differences in pre-marital cohabitation reflect variation in family formation processes (Heuveline and Timberlake 2004): In Bulgaria, for example, the high prevalence of premarital cohabitation is due to short-term cohabitation prior to the wedding (and with the same partner) (Philipov and Jasilioniene 2008).

\subsection{Results}

\subsubsection{The Risk of Divorce Over Marital Duration and Stages of the Long Transition}

Figures 4.3a-g describe the risks of divorce (hazard rates) across different time periods by duration of the marriage in the seven countries. For the most part, we identify the common duration-specific pattern of divorce in which divorce rates increase during the first years of marriage, and decrease and stabilize thereafter. One can also detect clear cross-national variation in divorce rates as well as in their levels across time periods. Divorce rates were the lowest in Bulgaria and Romania, whereas they were the highest in Estonia and Russia. Except for Bulgaria and Romania, where divorce rates remained stable throughout the observation period, changes in divorce rates can be observed for the other CEE and FSU countries. In the period of perestroika, divorce rates decreased in Russia and Estonia, while they increased in Lithuania and Hungary. From the time period 1989-1991 onward, Estonia, Hungary and Lithuania deviate from general divorce rate patterns. In these countries, divorce rates remained rather stable or increased with marriage duration. Similar trends can be observed for Poland from 1992 onward. In Estonia, Hungary and Poland, the time period 1992-1995 indicates an increase in divorce rates, whereas in Lithuania and Russia, divorce rates started to increase constantly from 1996. Compared to Estonia, where divorce rates seemed to recover from 2001 on, Russia, Hungary, Lithuania and Poland did not face a decrease in divorce rates.

Overall, the descriptive findings reveal rather considerable cross-national variation both in the level of divorce as well as its temporal pattern during the transition from communism to market-based economies. They suggest that the transition from communism could have affected divorce, although the effects seem to have been country-specific. However, these descriptive findings do not tell us whether differences persist once adjusting for compositional factors. Any differences in divorce rates over the transition can reflect changing composition of marriages, such as the educational distributions of married couples, or changing family formation behaviors in terms of postponement of family formation, increasing cohabitation, or changes in fertility. Each of these factors also predicts divorce, which means they may independently account for changes in divorce rates. 

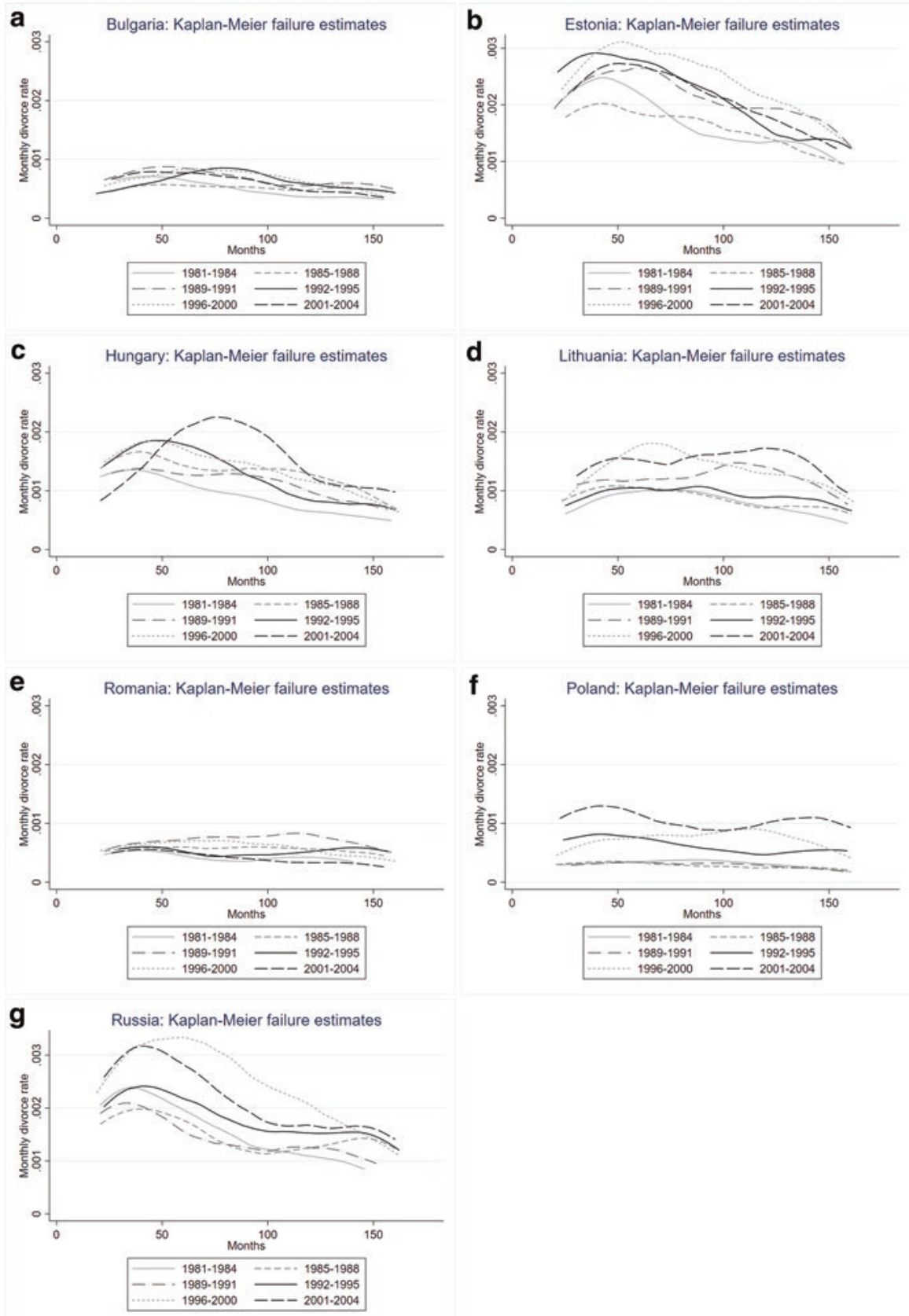

Fig. 4.3 (a-g) Monthly divorce rates by synthetic marriage cohort in Bulgaria, Estonia, Hungary, Lithuania, Poland, Romania, and Russia 


\subsubsection{Event History Regression of Divorce Over the Long Transition}

The Kaplan-Meier estimates shown above presented descriptive findings of duration-specific divorce rates in the seven countries. However, because these findings did not adjust for compositional factors, any period differences (or lack thereof) in divorce rates can reflect changing composition of marriages, such as the educational distributions of married couples, or changing family formation behaviors in terms of postponement of family formation, increasing cohabitation, or changes in fertility. Each of these factors also predict divorce, which means they may independently account for changes in divorce rates.

Table 4.2 presents results from two event history models on the risk of divorce, each estimated separately for the seven countries. The first model shows estimates of differences in divorce risk by historical period, when only controlling for gender of the respondent and duration of the marriage, whereas the second model controls for education, its interaction with gender, age at marriage, whether the respondent had cohabited before marrying, number of children, and whether the marriage involved children born before the union started. The second model was estimated in order to assess whether any changes in divorce risk over periods-and especially, marriages that began around the transition from communism-remained after changes in family formation behaviour were taken into account.

Two general findings are clear. First, the results confirm the descriptive results of a lack of any uniform pattern in divorce risks over the transition from communism to market-based economies. Second, with a few exceptions, changes in family formation behavior and the composition of marriages do not explain the differences in divorce risks over time. Little difference in the period estimates appeared between Model 1 and 2, where results are adjusted for educational attainment, fertility behavior, cohabitation history, and presence of stepchildren in the latter. Increased divorce risk in certain periods of the transition from communism were somewhat attenuated in the full model in Hungary, Poland and Russia. Heightened divorce risk during the collapse of communism in Bulgaria (1989-1998), in contrast, was not revealed until adjusting for compositional differences.

Period-specific differences are observed in Model 2 after adjusting for compositional changes over time. In each country, divorce rates had increased at some point during the observation period from the reference period of 1981-1984. However, the countries differ clearly in when the increase first took place, and whether it was sustained or temporary. The period of perestroika is when changes related to the transition from communism began, and we note an increase in divorce risks only in two countries: Hungary and Romania. In Hungary, this early shift in divorce rates held stable throughout the period we studied (until 2004). Romania, in contrast, saw further increases in divorce rates-with a peak in 1989-1991-but then a return to earlier rates by the 2001-2004 period.

Bulgaria, Lithuania, and Estonia experienced the first increase in divorce rates during the years in which the actual collapse of communism occurred (1989-1991). 


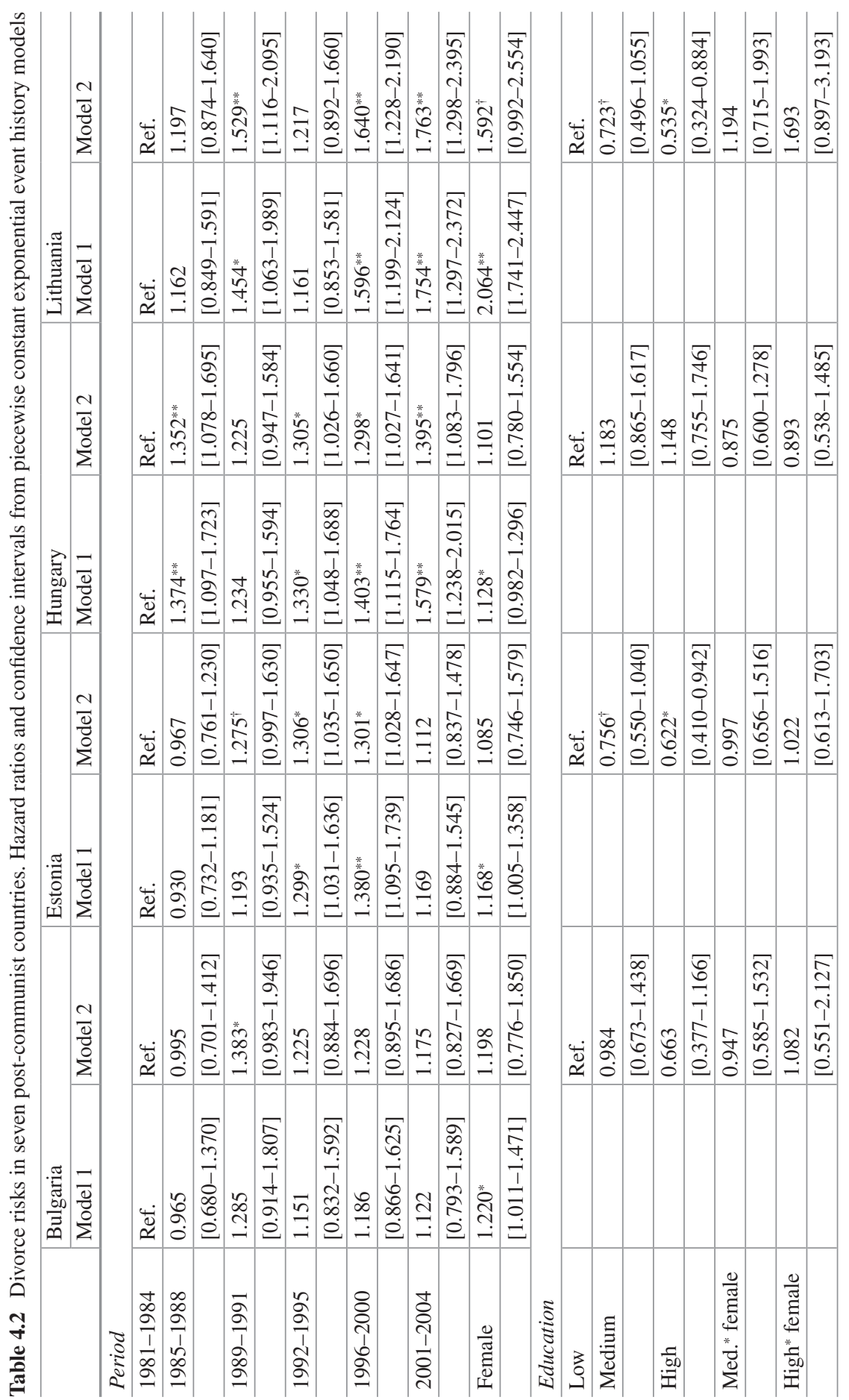




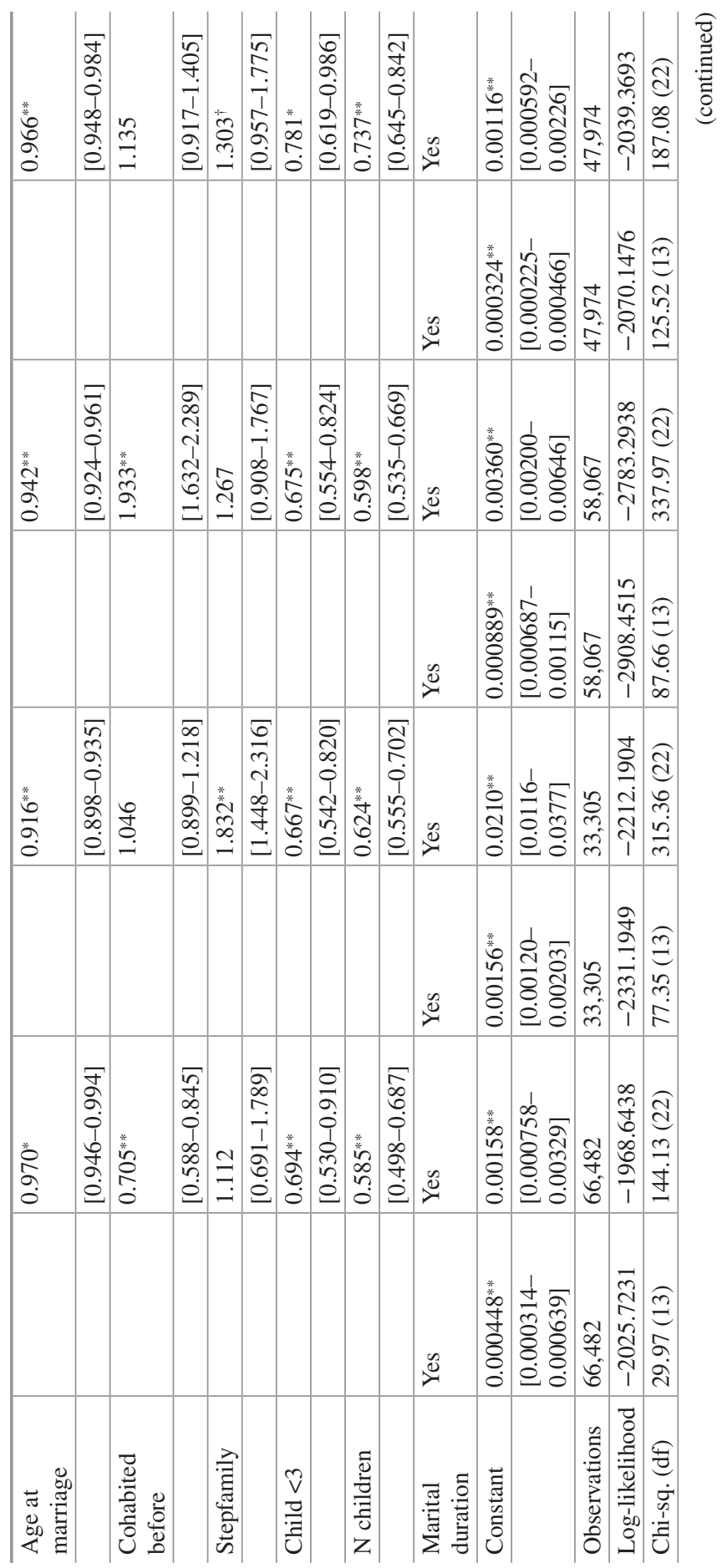




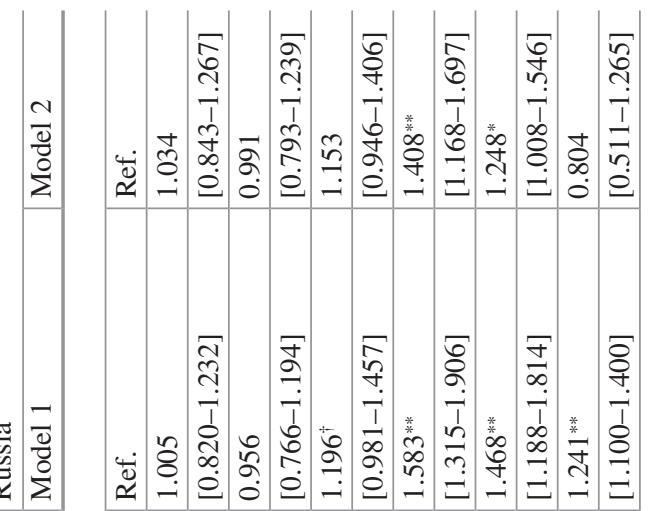

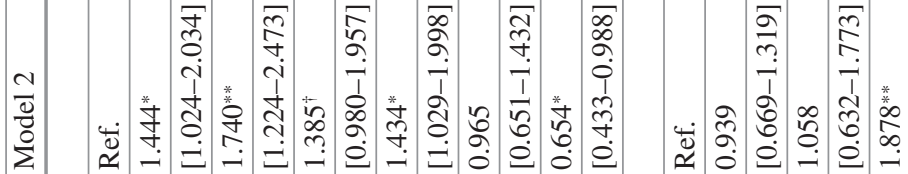

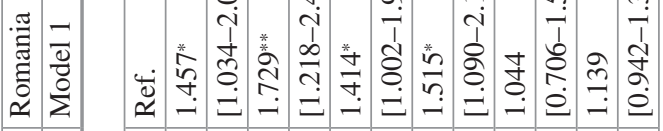

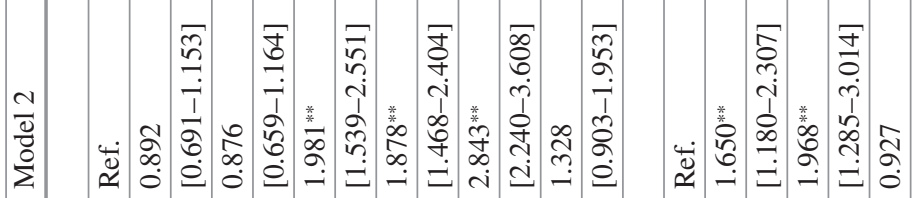

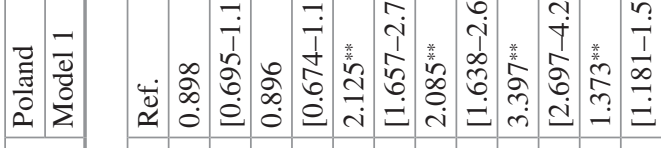

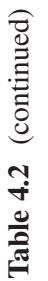

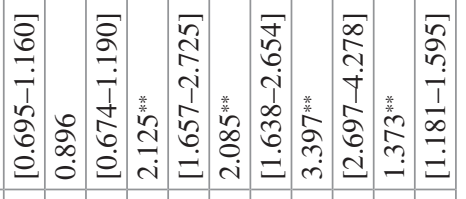

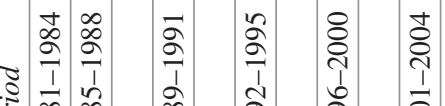

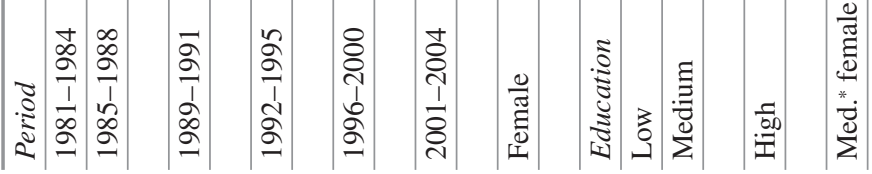




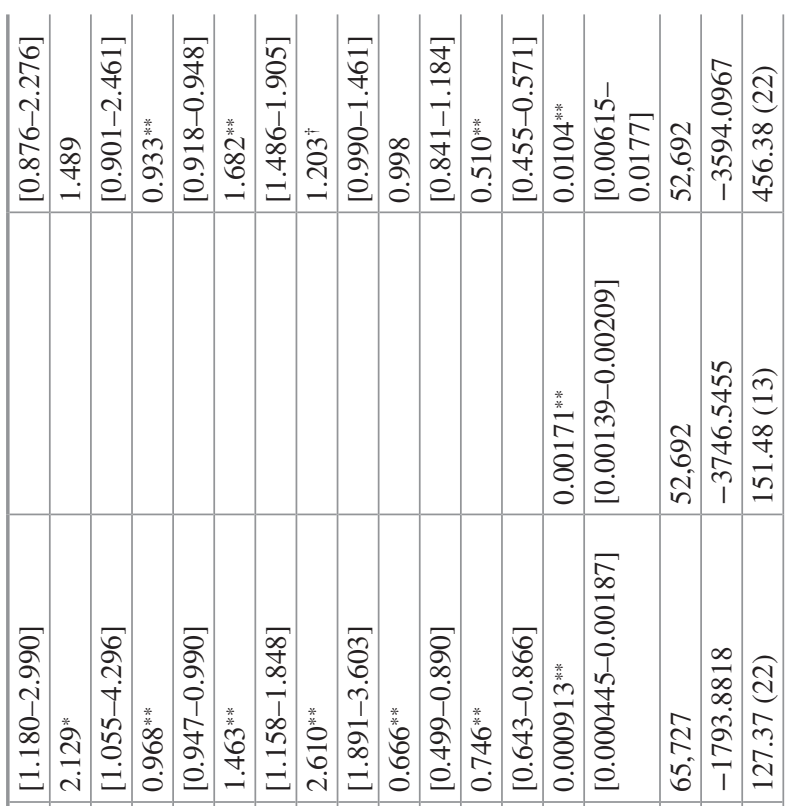

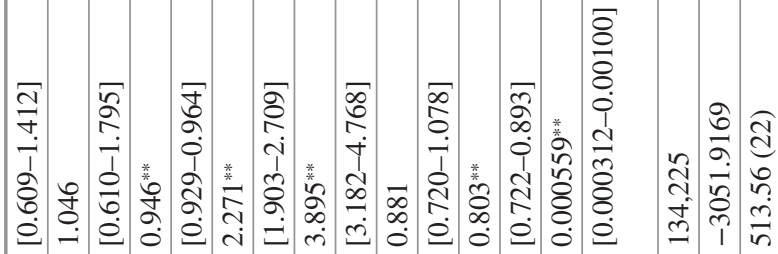

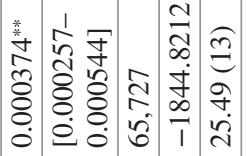

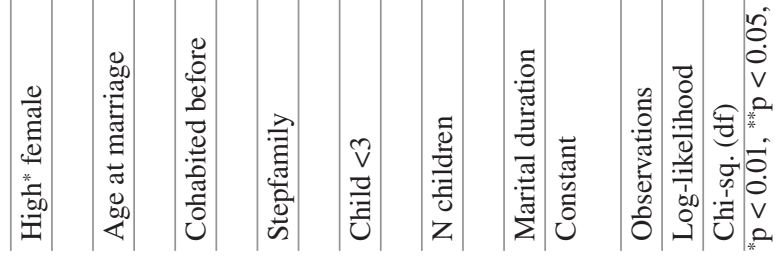


This relatively small increase in divorce rates was short-lived in Bulgaria, where rates immediately fell again and held stable in our observation period. In Lithuania, after a temporary decrease in 1992-1995, we see rather a steady increase that continued for most of the following periods. Divorce rates increased for the first time during the 1989-1991 period also in Estonia, even though the difference from the reference period is statistically significant only at the $10 \%$ level. Estonian divorce rates remained elevated throughout the 1990s, but returned to the starting level after the turn of the millennium.

Poland and Russia are two countries in which divorce rates began to increase after the transition period of 1989-1991. Although from a low initial level (see Fig. 4.3f), Polish divorce rates increased sharply starting from the 1992-1995 period, and continued to increase until the end of the follow-up period in 2001-2004. In Russia, on the other hand, divorce rates remained stable through the 1980s and the transition years of the early 1990s, and increased only in the late 1990s to remain elevated also in the early 2000s.

In sum, our results show that divorce rates were sensitive to the societal change in all countries, at least temporarily, but with varying patterns. Increased divorce risks that accompanied the transition from communism appear to have been temporary or short-term reactions to societal change in Bulgaria, Estonia and Romania, whereas in Lithuania and Poland the transition and its aftermath seemed to have triggered a more lasting increasing trend. While Hungary was early in showing a change in divorce rates and Russia was late, a continued increasing trend was not evident in either case.

\subsection{Conclusions}

In this study, we analyzed trends in divorce risks in seven post-communist countries with a particular interest in whether divorce in these countries was affected by the long transition-ranging from the gradual demise of the communist economic system in the 1980s to the years of economic recovery and dawning accession to the European Union in Eastern Europe-from communism to market-based societies. The collapse of communism was one of the defining geopolitical events of latetwentieth century Europe with major implications for the lives of the citizens who went through the transition. This has been documented in a range of studies that have focused on health and mortality, alcohol use, and family formation and fertility. Yet research on developments in divorce rates over the transition has been markedly absent.

Our comparison covered seven post-communist countries-Bulgaria, Estonia, Hungary, Lithuania, Poland, Romania, and Russia - that despite all having gone through the transition, differed from one another in several ways. Some were part of the Soviet Union whereas others were not. They also varied in terms of religious heritage and religiosity, and the long-term economic and social success in transitioning to the new societal system. 
Our explorative analysis of divorce trends during the long transition from communism sought to answer three questions. First, we asked how divorce risks developed over the long transition and second, whether any trends be accounted for by changes in the educational and demographic composition of marriages. We discussed how theoretically, the transition and the economic, social and legal changes that accompanied it could lead either to an increase or a decrease in divorce rates. Our results showed that in each of the seven countries, we could find signs of increased divorce risks at some stages of the transition. Although we cannot completely rule out the possibility that these findings reflect more secular trends in divorce, the timing patterns of the increase, or the start of the increase, strongly suggest that the transition played a role.

Furthermore, we found that adjusting for educational attainment and family demographic characteristics did not, for the most part, account for these increases. This finding contrasts the conclusion by Philipov and Dorbritz (2003) of no apparent effect of the transition on aggregated divorce rates. This suggests that our comparative analysis of divorce trends in post-communist countries with micro-level data - the first of its kind-revealed trends that remained uncovered in an aggregatelevel analysis.

As an answer to our third question, we found that despite signs of a transition effect in each countries, the exact pattern of divorce rates over the long transition varied markedly between the seven countries. The seven countries started from very different levels of divorce, and no clear pattern of divorce trends was found during the long transition. In three countries-Bulgaria, Lithuania, and Estonia-divorce rates increased during the period of their detachment from communist rule in 1989-1991; additionally, in Romania they peaked during this period. Yet in Bulgaria, this increase was only temporary (and from a low level), and divorce rates returned later to their initial levels also in Estonia and Romania. Lithuania differed from this pattern, and their divorce rates continued to increase-after a temporary dip in 1992-1995 - until the last observation period of 2001-2004.

In other countries-Hungary and Romania-divorce rates had increased from the 1981-1984 level already in 1985-1988. Hungary tightened its divorce laws in the late 1980s, as a result of earlier increases in divorce (Bukodi and Róbert 2003; Spéder and Kamarás 2008), which may have contributed to the temporary decrease in divorce in 1989-1991. But otherwise, Hungarian divorce rates then remained stable until 2001-2004. Romanian divorce rates, which together with the Bulgarian ones were the lowest of the seven countries, peaked in 1989-1991 and decreased later, ending up in 2001-2004 at the same level as in 1981-1984. In Poland, divorce rates were low in the 1980s but increased rapidly from 1992-1995 onward, overlapping with economic revival in Poland. The overlap between post-transition economic crisis and growth in divorce was different in Russia. Even though the collapse of the Soviet Union led to well-documented economic and social problems, Russian divorce rates increased only in 1996-2000, overlapping with the late-1990s economic collapse.

To conclude, although the economic and social experiences during long transition from communism shared many similarities-the gradual decline of the 
communist system in the 1980 s, the economic crises of the immediate aftermath of the collapse of communism in 1989-1991 as well as economic uncertainties in the 1990s, and the economic recovery during the early years of the millennium-this was not matched by a uniform trend of divorce. Rather, we find clear differences in how and when the transition shaped marital stability, and likely reflected the different historical starting points and traditions, and the national idiosyncracies in the adaptations to market-based democracies. Although our exploratory analysis could not shed light on these idiosyncratic explanations, it did show that the effects of even major societal upheavals on divorce are contingent on societal context. Future research can shed more light on the contextual features that can shape the impacts of major societal ruptures on divorce.

Acknowledgement We thank Brienna Perelli-Harris for her previous work on the Harmonized Histories (www.nonmarital.org), which we followed closely in the construction of CLiCR. In addition, we thank UNECE for the Family and Fertility Survey and the Generations and Gender Surveys: these data were obtained from the GGP Data Archive and were created by the organizations and individuals listed at http://www.unece.org/pau/ggp/acknowledge.htm.

Funding We gratefully acknowledge the Swedish Research Council (Vetenskapsrådet) via the Linnaeus Center for Social Policy and Family Dynamics in Europe (SPaDE), grant registration number 349-2007-8701. We also acknowledge financial support from the Stockholm Centre on Health of Societies in Transition (SCOHOST) at Södertörn University for supporting Aija Duntava and Sunnee Billingsley's efforts to harmonize CLiCR data. Research reported in this article is also part of the project Critical Life Events and the Dynamics of Inequality: Risk, Vulnerability, and Cumulative Disadvantage (CRITEVENTS), which is part of the joint New Opportunities for Research Funding Agency Cooperation in Europe (NORFACE) research program "Dynamics of Inequality Across the Life-course" (DIAL). DIAL is funded by the European Commission via an European Research Area Network (ERA-NET) Co-fund grant (724363).

This chapter also benefited from the support of the Centre for Population, Family and Health $(\mathrm{CPFH})$ at the University of Antwerp and the Flemish Agency of Innovation and Entrepreneurship (Grant number: 140069), which enabled Open Access to this chapter.

\section{References}

Amato, P. R., \& Beattie, B. (2011). Does the unemployment rate affect the divorce rate? An analysis of state data 1960-2005. Social Science Research, 40(3), 705-715. https://doi.org/10.1016/j. ssresearch.2010.12.012.

Avdeev, A., \& Monnier, A. (2000). Marriage in Russia: A complex phenomenon poorly understood. Population: An English Selection, 12, 7-50. Retrieved from http://www.jstor.org/ stable/3030243

Barr, N. (2001). Reforming welfare states in post-communist countries. In L. T. Orlowski (Ed.), Transition and growth in post-communist countries: The ten-year experience (pp. 169-218).

Becker, G. S. (1981). A treatise on the family. Cambridge, MA: Harvard U.P.

Becker, C. M., \& Hemley, D. D. (1998). Demographic change in the former Soviet Union during the transition period. World Development, 26(11), 1957-1975. https://doi.org/10.1016/ S0305-750X(98)00113-2.

Billingsley, S. (2010). The post-communist fertility puzzle. Population Research and Policy Review, 29(2), 193-231. https://doi.org/10.1007/s11113-009-9136-7. 
Billingsley, S. (2011). Economic crisis and recovery: Changes in second birth rates within occupational classes and educational groups. Demographic Research, 24(16), 375-406. Retrieved from https://ezp.sub.su.se/login?url=http://search.ebscohost.com/login.aspx?direct=true \&db=edsdo j\&AN=edsdoj.6e8c053c837c4891bfff1c2e2b16bd64\&site=eds-live \&scope $=$ site

Billingsley, S., \& Duntava, A. (2017). Putting the pieces together: 40 years of fertility trends across 19 post-socialist countries. Post-Soviet Affairs, 33(5). https://doi.org/10.1080/10605 86X.2017.1293393.

Blanchard O. (1997). The economics of post-communist transition. Oxford: Oxford University Press. Retrieved from https://ezp.sub.su.se/login?url=http://search.ebscohost.com/login.aspx? direct $=$ true $\& \mathrm{db}=$ edsebk $\& A N=264981 \&$ site $=$ eds-live $\&$ scope $=$ site

Blossfeld, H.-P., Golsch, K., \& Rohwer, G. (2007). Event history analysis with Stata. Mahwah: Taylor and Francis. Retrieved from http://ebookcentral.proquest.com/lib/sub/detail. action?docID=321597

Bodnar, J., \& Böröcz, J. (1998). Housing advantages for the better connected? Institutional segmentation, settlement type and social network effects in Hungary's late state-socialist housing inequalities. Social Forces, 76(4), 1275-1304.

Böheim, R., \& Ermisch, J. (2001). Partnership dissolution in the UK - The role of economic circumstances. Oxford Bulletin of Economics \& Statistics, 63(2), 197-208. Retrieved from https://ezp.sub.su.se/login?url=http://search.ebscohost.com/login.aspx direct=true \&db=buh\& $\mathrm{AN}=4550022$ \&site $=$ eds-live \&scope $=$ site

Bohle, D., \& Greskovits, B. (2007). Neoliberalism, embedded neoliberalism and neocorporatism: Towards transnational capitalism in Central-Eastern Europe. West European Politics, 30(3), 443-466. https://doi.org/10.1080/01402380701276287.

Brainerd, E. (1998). Market reform and mortality in transition economies. World Development, 26(11), 2013-2027. https://doi.org/10.1016/S0305-750X(98)00096-5.

Brainerd, E. (2000). Women in transition: Changes in gender wage differentials in Eastern Europe and the former Soviet Union. Industrial and Labor Relations Review, 54(1), 138-162.

Bukodi, E., \& Róbert, P. (2003). Union disruption in Hungary. International Journal of Sociology, 33(1), 64-94. Retrieved from http://ezproxy.stir.ac.uk/login?url=http://search.ebscohost.com/ login.aspx ?direct $=$ true $\& \mathrm{db}=$ sih $\& A N=9488536 \&$ site $=$ ehost-live

Clapham, D., \& Kintrea, K. (1996). Analyzing housing privatization. In D. Clapham, K. Kintrea, J. Hegedüs, \& I. Tosics (Eds.), Housing privatization in Eastern Europe (pp. 1-15). Greenwood Publishing Group.

Cohen, P. N. (2014). Recession and divorce in the United States, 2008-2011. Population Research and Policy Review, 33(5), 615-628. https://doi.org/10.1007/s11113-014-9323-z.

Conger, R. D., Elder, G. H., Lorenz, F. O., Conger, K. J., Simons, R. L., Whitbeck, L. B., et al. (1990). Linking economic hardship to marital quality and instability. Journal of Marriage and Family, 53(3), 643-656. https://doi.org/10.2307/352931.

Cooke, L. P., Erola, J., Evertsson, M., Gähler, M., Härkönen, J., Hewitt, B., et al. (2013). Labor and love: Wives' employment and divorce risk in its socio-political context. Social Politics: International Studies in Gender, State \& Society, 20(4), 482-509.

Deacon, B. (1987). Sociopolitics or social policy: Bulgarian welfare in transition? International Journal of Health Services: Planning, Administration, Evaluation, 17(3), 489-514. https://doi. org/10.2190/45LA-T4L0-341R-276C.

Degtiar, L. (2000). The transformation process and the status of women. Problems of Economic Transition, 43(7), 7-19. Retrieved from https://ezp.sub.su.se/login?url=http://search.ebscohost.com/login.aspx?direct=true $\& \mathrm{db}=$ buh $\& A N=4298278 \&$ site $=$ eds-live $\&$ scope $=$ site

Dvorak, J. (2013). Lithuania. In Cultural sociology of divorce: An encyclopedia (pp. 720-721). Thousand Oaks: SAGE. https://doi.org/10.4135/9781452274447.n259.

EUROSTAT. (2018). Divorce indicators. Retrieved from http://appsso.eurostat.ec.europa.eu/nui/ submitViewTableAction.do.

Fajth, G. (1999). Social security in a rapidly changing environment: The case of the postcommunist transformation. Social Policy \& Administration, 33(4), 416-436. Retrieved from https://onlinelibrary.wiley.com/doi/epdf/10.1111/1467-9515.00161. 
Fischer, T., \& Liefbroer, A. C. (2006). For richer, for poorer: The impact of macroeconomic conditions on union dissolution rates in the Netherlands 1972-1996. European Sociological Review, 22(5), 519-532. https://doi.org/10.1093/esr/jcl013.

Fitzpatrick, J., \& Kostina-Ritchey, E. (2013). Russia. In Cultural sociology of divorce: An encyclopedia (pp. 1049-1050). Thousand Oaks: SAGE. https://doi.org/10.4135/9781452274447.n379.

Frejka, T. (2008). Overview chapter 5: Determinants of family formation and childbearing during the societal transition in central and Eastern Europe. Demographic Research, 19, 139-170. https://doi.org/10.4054/DemRes.2008.19.7.

Gerber, T., \& Berman, D. (2010). Entry to marriage and cohabitation in Russia, 1985-2000: Trends, correlates, and implications for the second demographic transition. European Journal of Population, 26(1), 3-31. Retrieved from http://10.0.3.239/s10680-009-9196-8

Gerber, T., \& Hout, M. (2004). Tightening up: Declining class mobility during Russia's market transition. American Sociological Review, 69(5), 677. Retrieved from https://ezp.sub.su.se/ login?url=http://search.ebscohost.com/login.aspx?direct=true\&db=edsjsr\&AN=edsjsr.359303 $4 \&$ site $=$ eds-live $\&$ scope $=$ site

Gerber, T. P., \& Hout, M. (2009). Tightening up : Declining class mobility tightening transition during Russia 's market. American Sociological Review, 69(5), 677-703.

Gimpelson, V. (2001). The politics of labor-market adjustment: The case of Russia. In J. Kornai, S. Haggard, \& R. R. Kaufman (Eds.), Reforming the state (pp. 25-52). Cambridge: Cambridge University Press. https://doi.org/10.1017/CBO9781139175296.003.

González-Val, R., \& Marcén, M. (2017). Divorce and the business cycle: A cross-country analysis. Review of Economics of the Household, 15(3), 879-904. https://doi.org/10.1007/ s11150-016-9329-x.

Goode, W. J. (1993). World changes in divorce patterns. New Haven: Yale University Press.

Guo, G. (1993). Event-history analysis for left-truncated data. Sociological Methodology, 23, 217 243. https://doi.org/10.2307/271011.

Härkönen, J. (2014). Divorce: Trends, patterns, causes and consequences. In J. Treas, J. L. Scott, \& M. Richards (Eds.), The sociology of families (pp. 303-323). Wiley-Blackwell.

Härkönen, J., \& Dronkers, J. (2006). Stability and change in the educational gradient of divorce. A comparison of seventeen countries. European Sociological Review, 22(5), 501-517. https:// doi.org/10.1093/esr/jc1011.

Hegedüs, J. (2013). The transformation of the social housing sector. In J. Hegedüs, M. Lux, \& N. Teller (Eds.), Social housing in transition countries (pp. 3-33). New York: Routledge.

Hegedüs, J., \& Tosics, I. (1992). Conclusion: Past tendencies and recent problems of the east European housing model. In B. Turner, J. Hegedüs, \& I. Tosics (Eds.), The reform of housing in Eastern Europe and the Soviet Union (pp. 318-335). London/New York: Routledge.

Hellerstein, J. K., \& Morrill, M. S. S. (2009). Booms, busts, and divorce. The B.E. Journal of Economic Analysis \& Policy, 9(1). Retrieved from https://ezp.sub.su.se/login?url=http:// search.ebscohost.com/login.aspx?direct=true $\& d b=e d s w s s \& A N=000294466000010 \&$ site $=$ eds-live \&scope $=$ site

Heuveline, P., \& Timberlake, J. M. (2004). The role of cohabitation in family formation: The United States in comparative perspective. Journal of Marriage and Family, 66(5), 1214-1230. https://doi.org/10.1111/j.0022-2445.2004.00088.x.

Hoem, J. M. (1996). The harmfulness or harmlessness of using an anticipatory regressor: how dangerous is it to use education achieved as of 1990 in the analysis of divorce risks in earlier years? Yearbook of Population Research in Finland, 33, 34-43. Retrieved from https://ezp.sub. su.se/login?url=http://search.ebscohost.com/login.aspx?direct=true \&db=edsdoj\&AN=edsdoj. 319e8a29ab1a47e696b6e10f5f9c714d\&site=eds-live\&scope=site

Hoem, J. M., Kostova, D., Jasilioniene, A., \& Mureşan, C. (2009). Traces of the second demographic transition in four selected countries in central and Eastern Europe: Union formation as a demographic manifestation. European Journal of Population, 25(3), 239-255. https://doi. org/10.1007/s10680-009-9177-y. 
Hussar, A. (2017). Estonia: Prospects for steady improvement. Private rental housing in transition countries: An alternative to owner occupation? Faculty of Law, University of Tartu: Palgrave Macmillan. https://doi.org/10.1057/978-1-137-50710-5_9.

Jasilioniene, A. (2007). Premarital conception and divorce risk in Russia in the light of the GGS data (MPIDR Working Paper, Vol. 25).

Karabchuk, T. (2017). Marriage and divorce, 1994-2014. In T. Karabchuk, K. Kumo, \& E. Selezneva (Eds.), Demography of Russia (pp. 115-155). London: Macmillan Publishers Ltd..

Katus, K., Puur, A., Poldma, A., \& Sakkeus, L. (2007). First union formation in Estonia, Latvia and Lithuania: Patterns across countries and gender. Demographic Research, 17(10), 247-300. Retrieved from https://ezp.sub.su.se/login?url=http://search.ebscohost.com/login. aspx ?direct $=$ true $\& d b=$ edsdoj\&AN=edsdoj.07633c0fe3e44b53a0342ce87418938f \&site=eds-li ve\&scope $=$ site

Keenan, K., Kenward, M. G., Grundy, E., \& Leon, D. A. (2013). Longitudinal prediction of divorce in Russia: The role of individual and couple drinking patterns. Alcohol and Alcoholism, 48(6), 737-742. https://doi.org/10.1093/alcalc/agt068.

Khazova, O. A. (2012). Marriage and divorce law in Russia and the Baltic States: Overview of recent changes. In H. Carlbäck, Y. Gradskova, \& Z. Kravchenko (Eds.), And they lived happily ever after (pp. 251-273). Budapest/New York: Central European University Press.

Khotkina, Z. (2001). Female unemployment and informal employment in Russia. Problems of Economic Transition, 43(9), 20-33. Retrieved from https://ezp.sub.su.se/login?url= http://search.ebscohost.com/login.aspx?direct $=$ true $\& \mathrm{db}=$ buh $\& A N=4400034 \&$ site $=$ eds-live \&scope=site

Koytcheva, E., \& Philipov, D. (2008). Bulgaria: Ethnic differentials in rapidly declining fertility. Demographic Research, 19, 361-401. https://doi.org/10.4054/DemRes.2008.19.13.

Kraft, K. (2001). Unemployment and the separation of married couples. Kyklos, 54(1), 67-87. Retrieved from http://onlinelibrary.wiley.com/journal/10.1111/\%28ISSN\%291467-6435/ issues

Kte'pi, B. (2013). Bulgaria. In Cultural sociology of divorce: An encyclopedia (pp. 157-158). Thousand Oaks: SAGE. https://doi.org/10.4135/9781452274447.n61.

LaFont, S. (2001). One step forward, two steps back: Women in the post-communist states. Communist and Postcommunist Studies, 34(2), 203. Retrieved from https://ezp.sub.su.se/ login?url=http://search.ebscohost.com/login.aspx?direct=true \&db=edsbl\&AN=RN09548050 $0 \&$ site $=$ eds-live \&scope $=$ site

Lesthaeghe, R., \& Surkyn, J. (2002). New forms of household formation in central and Eastern Europe: Are they related to newly emerging value orientations? In UN. ECE. Secretariat (Ed.), Economic survey of Europe (pp. 197-217).

Levinger, G. (1976). A social psychological perspective on marital dissolution. Journal of Social Issues, 32(1), 21-47. Retrieved from https://ezp.sub.su.se/login?url=http://search.ebscohost. com/login.aspx $?$ direct $=$ true $\& d b=$ sxi $\& A N=16366671 \&$ site=eds-live $\&$ scope $=$ site

Lobodzinska, B. (1983). Divorce in Poland: Its legislation, distribution and social context. Journal of Marriage and Family, 45(4), 927-942. https://doi.org/10.2307/351806.

Lux, M., \& Sunega, P. (2014). Public housing in the post-socialist states of central and eastern. Europe: Decline and an Open Future/Housing Studies/Taylor \& Francis. https://doi.org/10.10 80/02673037.2013.875986.

Lyngstad, T. H., \& Jalovaara, M. (2010). A review of the antecedents of union dissolution. Demographic Research, 23, 257-292. https://doi.org/10.4054/DemRes.2010.23.10.

Maslauskaite, A., Jasilioniene, A., Jasilionis, D., Stankuniene, V., \& Shkolnikov, V. M. (2015). Socio-economic determinants of divorce in Lithuania: Evidence from register-based census-linked data. Demographic Research, 33(1), 871-908. https://doi.org/10.4054/ DemRes.2015.33.30. 
Mckee, M., Shkolnikov, V., \& Leon, D. A. (2001). Alcohol is implicated in the fluctuations in cardiovascular disease in Russia since the 1980s. Annals of Epidemiology, 11(1), 1-6. https:// doi.org/10.1016/S1047-2797(00)00080-6.

Morton, H. W. (1979). Housing problems and policies of Eastern Europe and the Soviet Union. Studies in Comparative Communism, 12(4), 300-321. https://doi.org/10.1016/ S0039-3592(79)90271-0.

Moskoff, W. (1983). Divorce in the USSR. Journal of Marriage and Family, 45(2), 419-425. https://doi.org/10.2307/351520.

Müller, O. (2009). Religiosity in central and Eastern Europe : Results from the PCE 2000 survey in comparison. Wiesbaden: VS Verl. für Sozialwiss. Retrieved from https://ezp.sub.su.se/ login?url=http://search.ebscohost.com/login.aspx?direct=true \&db=edsgsl\&AN=edsgsl.71218 $4 \&$ site $=$ eds-live $\&$ scope $=$ site

Mureşan, C. (2007). Family dynamics in pre- and post-transition Romania: A life-table description (MPIDR Working Paper, 18(0), p. 70). Retrieved from http://www.demogr.mpg.de/papers/ working/wp-2007-018.pdf

Mureşan, C., Haraguş, P. T., Haraguş, M., \& Schröder, C. (2008). Romania: Childbearing metamorphosis within a changing context. Demographic Research, 19, 855-906. https://doi. org/10.4054/DemRes.2008.19.23.

Muszyńska, M. (2008). Women's employment and union dissolution in a changing socioeconomic context in Russia. Demographic Research, 18, 181-204. https://doi.org/10.4054/ DemRes.2008.18.6.

Muszyńska, M., \& Kulu, H. (2007). Migration and union dissolution in a changing socio-economic context: The case of Russia. Demographic Research, 17, 803-820. https://doi.org/10.4054/ DemRes.2007.17.27.

Nedoluzhko, L., \& Agadjanian, V. (2015). Between tradition and modernity: Marriage dynamics in Kyrgyzstan. Demography, 52(3), 861-882. https://doi.org/10.1007/s13524-015-0393-2.

Palmer, L., \& Molenda-Kostanski, Z. (2013). Poland. In Cultural sociology of divorce: An encyclopedia (pp. 937-974). Thousand Oaks: SAGE. https://doi.org/10.4135/9781452274447.n355.

Pantea, M.-C. (2013). Romania. In Cultural sociology of divorce: An encyclopedia (pp. 10471048). Thousand Oaks: SAGE. https://doi.org/10.4135/9781452274447.n378.

Pascall, G., \& Manning, N. (2000). Gender and social policy: Comparing welfare states in central and Eastern Europe and the former Soviet Union. Journal of European Social Policy, 10(3), 240-266. https://doi.org/10.1177/a013497.

Perelli-Harris, B., Berrington, A., Sánchez Gassen, N., Galezewska, P., \& Holland, J. A. (2017). The rise in divorce and cohabitation: Is there a link? Population \& Development Review, 43(2), 303-329. Retrieved from http://10.0.4.87/padr.12063

Philipov, D., \& Dorbritz, J. (2003). Demographic consequences of economic transition in countries of central and eastern Europe. Population studies (Vol. 45). Strasbourg: Council of Europe Publishing. https://doi.org/10.2307/351806.

Philipov, D., \& Jasilioniene, A. (2008). Union formation and fertility in Bulgaria and Russia: A life table description of recent trends. Demographic Research, 19, 2057-2114. https://doi. org/10.4054/DemRes.2008.19.62.

Robila, M. (2004). Child development and family functioning within the Romanian context. In Families in Eastern Europe (pp. 141-154). https://doi.org/10.1016/S1530-3535(04)05009-5.

Rootalu, K. (2010). The effect of education on divorce risk in Estonia. Trames, 14(1), 21-33.

Schaller, J. (2013). For richer, if not for poorer? Marriage and divorce over the business cycle. Journal of Population Economics, 26(3), 1007-1033. https://doi.org/10.1007/s00148-012-0413-0.

Sobotka, T. (2011). Fertility in central and Eastern Europe after 1989: Collapse and gradual recovery. Historical Social Research/Historische Sozialforschung, 36(2 (136)), 246. Retrieved from https://ezp.sub.su.se/login?url=http://search.ebscohost.com/login.aspx?direct=true\&db=edsjsr $\& A N=$ edsjsr.41151282\&site=eds-live $\&$ scope $=$ site

Sobotka, T., Skirbekk, V., \& Philipov, D. (2011). Economic recession and fertility in the developed world economic recession and fertility in the developed. Population and 
Development Review, 37(2), 267-306. Retrieved from http://onlinelibrary.wiley.com/ doi/10.1111/j.1728-4457.2011.00411.x/abstract

Solodnikov, V. V. (2016). Social research of divorce in USSR and Russia. In divorce, separation and remarriage: The transformation of family (pp. 301-326). https://doi.org/10.1108/ S1530-353520160000010012.

South, S. J. (1985). Economic conditions and the divorce rate: A time-series analysis of the postwar United States. Journal of Marriage and Family, 47(1), 31. https://doi.org/10.2307/352066.

Spéder, Z. (2005). The rise of cohabitation as first union and some neglected factors of recent demographic developments in Hungary. Demográfia, 48, 77-103.

Spéder, Z., \& Kamarás, F. (2008). Hungary: Secular fertility decline with distinct period fluctuations. Demographic Research, 19, 599-664. https://doi.org/10.4054/DemRes.2008.19.18.

Stankuniene, V., \& Jasilioniene, A. (2008). Lithuania: Fertility decline and its determinants. Demographic Research, 19, 705-742. https://doi.org/10.4054/DemRes.2008.19.20.

Szelewa, D., \& Polakowski, M. P. (2008). Who cares? Changing patterns of childcare in central and Eastern Europe. Journal of European Social Policy, 18(2), 115-131. https://doi. org/10.1177/0958928707087589.

Teplova, T. (2007). Welfare state transformation, childcare, and Women's work in Russia. Social Politics, 14(3), 284-322. Retrieved from https://ezp.sub.su.se/login?url=http://search.ebscohost.com/login.aspx?direct=true $\& \mathrm{db}=$ edsbl\&AN=RN216619003\&site=eds-live $\&$ scope $=$ site

Todorova, V. (2000). Family law in Bulgaria: Legal norms and social norms. International Journal of Law, Policy and the Family, 14(2), 148-181. https://doi.org/10.1093/lawfam/14.2.148.

TransMonEE. (2012). TransMonEE 2012 database. Geneva: UNICEF Regional Office for CEE/ CIS.

Tsenkova, S., Georgiev, G., Motev, S., \& Dimitrov, D. (1996). Bulgaria. In D. Clapham, J. Hegedüs, K. Kintrea, \& I. Tosics (Eds.), Housing privatization in Eastern Europe (pp. 97-119). Westport: Greenwood.

Turnock, D. (1990). Housing policy in Romania. In J. Sillince (Ed.), Housing policies in Eastern Europe and the Soviet Union (pp. 82-135). New York: Routledge.

Vignoli, D., Matysiak, A., Styrc, M., \& Tocchioni, V. (2018). The positive impact of women's employment on divorce: Context, selection, or anticipation? Demographic Research, 38(1), 1059-1110. https://doi.org/10.4054/DemRes.2018.38.51.

Weiss, Y., \& Willis, R. J. (1997). Match quality, new information, and marital dissolution. Journal of Labor Economics, 15(1), 293-329. Retrieved from https://ezp.sub.su.se/login?url=http:// search.ebscohost.com/login.aspx ?direct $=$ true $\& d b=e d s j s r \& A N=e d s j s r .2535409 \&$ site $=$ eds-live \&scope $=$ site

Open Access This chapter is licensed under the terms of the Creative Commons Attribution 4.0 International License (http://creativecommons.org/licenses/by/4.0/), which permits use, sharing, adaptation, distribution and reproduction in any medium or format, as long as you give appropriate credit to the original author(s) and the source, provide a link to the Creative Commons license and indicate if changes were made.

The images or other third party material in this chapter are included in the chapter's Creative Commons license, unless indicated otherwise in a credit line to the material. If material is not included in the chapter's Creative Commons license and your intended use is not permitted by statutory regulation or exceeds the permitted use, you will need to obtain permission directly from the copyright holder.

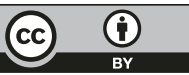

